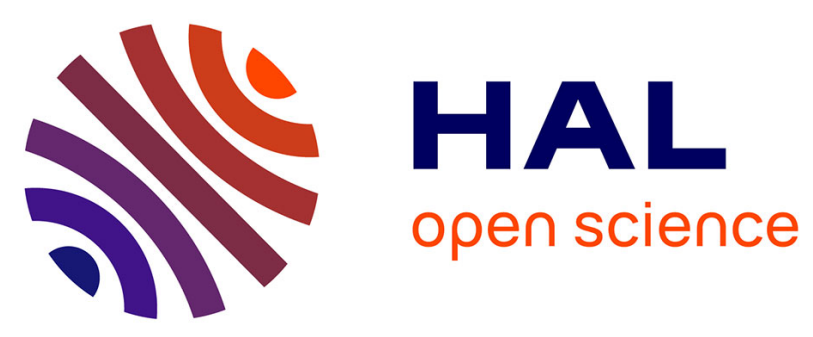

\title{
Oxidative stress in relation to reproduction, contaminants, gender and age in a long-lived seabird
}

David Costantini, Alizée Meillère, Alice Carravieri, Vincent Lecomte, Gabriele

Sorci, Bruno Faivre, Henri Weimerskirch, Paco Bustamante, Pierre Labadie, Hélène Budzinski, et al.

\section{To cite this version:}

David Costantini, Alizée Meillère, Alice Carravieri, Vincent Lecomte, Gabriele Sorci, et al.. Oxidative stress in relation to reproduction, contaminants, gender and age in a long-lived seabird. Oecologia, 2014, 175 (4), pp.1107 - 1116. 10.1007/s00442-014-2975-x . hal-01079023

\section{HAL Id: hal-01079023 \\ https://hal.science/hal-01079023}

Submitted on 31 Oct 2014

HAL is a multi-disciplinary open access archive for the deposit and dissemination of scientific research documents, whether they are published or not. The documents may come from teaching and research institutions in France or abroad, or from public or private research centers.
L'archive ouverte pluridisciplinaire HAL, est destinée au dépôt et à la diffusion de documents scientifiques de niveau recherche, publiés ou non, émanant des établissements d'enseignement et de recherche français ou étrangers, des laboratoires publics ou privés. 
Oxidative stress in relation to reproduction, contaminants, gender and age in a long-

lived seabird

\section{David Costantini • Alizée Meillere $•$ Alice Carravieri $\bullet$ Vincent Lecomte $\bullet$ Gabriele Sorci • Bruno Faivre • Henri Weimerskirch • Paco Bustamante • Pierre Labadie • Hélène Budzinski • Olivier Chastel}

D. Costantini

Department of Biology, University of Antwerp, Universiteitsplein 1, 2610 Wilrijk, Belgium Institute for Biodiversity, Animal Health and Comparative Medicine, Graham Kerr Building, University of Glasgow, Glasgow G12 8QQ, UK

E-mail: david.costantini@uantwerpen.be

Telephone: +32032652259

A. Meillere • A. Carravieri • V. Lecomte $\bullet$ H. Weimerskirch $\bullet \quad$ O. Chastel

Centre d'Etudes Biologiques de Chizé (CEBC), UPR 1934-CNRS, F-79360, France

G. Sorci • B. Faivre

Université de Bourgogne, UMR - CNRS 6282 Biogéosciences, 6 Boulevard Gabriel, F-21000 Dijon, France

P. Bustamante

Littoral Environnement Société (LIENSs), UMR 7266-CNRS, Université de La Rochelle, 2 rue Olympe de Gouges, F-17000 La Rochelle, France

P. Labadie $\bullet$ H. Budzinski

UMR 5805 EPOC-LPTC, Université Bordeaux, 351 Cours de la Libération, F-33405 Talence Cedex, France

Author Contributions: OC, DC, VL, GS and H.W. designed research; VL performed field work; DC, AM, AC, VL, GS, BF, HW, PB, PL and HB and OC performed research; DC analysed the data; and DC and OC wrote the paper. 


\begin{abstract}
Reproduction is a demanding activity for animals, since they must produce, and in some cases protect and provision, their young. It is often overlooked that demands of reproduction may also be exacerbated by exposure to contaminants. In this study, we make use of an exceptional long-term dataset to perform a cross-sectional study on the long-lived wandering albatross (Diomedea exulans) in order to test the effects of reproduction, persistent organic pollutants [POPs: pesticides and polychlorinated biphenyls (PCBs)], mercury, individual age (3-47 years), and sex on the levels of plasma oxidative damage and inflammation. The results of our study support the hypothesis that oxidative damage may be a physiological cost of reproduction and that individuals carrying higher levels of organic or non-organic contaminants have higher oxidative damage. Levels of the inflammatory protein haptoglobin were similar between breeding and nonbreeding birds, with the exception of breeding males which had the lowest levels of haptoglobin. Our data also show an effect of age and of organic contaminants on the plasma oxidative damage level, but not on plasma haptoglobin. In addition, plasma oxidative damage level increased with red blood cell mercury concentration in females but not in males. Hence, our study highlights that the harmful effects of contaminants may come through interaction with factors like life stage or gender, suggesting potential for high variation in susceptibility to contamination among individuals.
\end{abstract}

Keywords: Ageing • Inflammation $\bullet$ Mercury $\bullet$ Oxidative stress $\bullet$ POPs $\bullet$ Reproduction - Seabirds 


\section{Introduction}

Reproduction is a critical and demanding phase of animals' lives. Transition from a nonreproducing to a reproducing state is associated with hormonal changes that may incur in various metabolic costs to the individual (Ketterson and Nolan 1992). Reproductive effort (e.g., egg production, parental care) may also have costs that are paid later in life in terms of reduced survival or fecundity (Stearns 1992). Oxidative stress has been proposed as one cost associated with reproduction (Alonso-Alvarez et al. 2004; Wiersma et al. 2004; Costantini 2008; Metcalfe and Monaghan 2013). Oxidative stress is the rate at which oxidative damage is generated, which depends on a complex balance between pro- and antioxidant mechanisms, including repair systems (Halliwell and Gutteridge 2007). Such damage can contribute to cell senescence, loss in organ and organism performance, and may influence life-history strategies (Costantini 2008; Metcalfe and Alonso-Alvarez 2010). Progressive damage to biomolecules (e.g., oxidation of DNA, lipids or telomeres) may also trigger an inflammatory response, a mechanism used by the organism to protect itself from a stressful agent (Sorci and Faivre 2009; Jelena et al. 2013). Inflammation-inducible proteins, like haptoglobin, can limit the spread of oxidative damages across tissues by binding molecules with pro-oxidant activity (Jelena et al. 2013).

An individual that reproduces in a polluted environment is also faced with the need of controlling the action of contaminants because they can influence the immune activity, increase stress levels, or reduce survival of wild animals (Dell'Omo 2002; Koivula and Eeva 2010; Isaksson 2010). Interest in the interactions between contaminants and organism adaptation in a changing world has dramatically grown in the last few decades. It is, however, sometimes forgotten in ecological and behavioral studies that some of the among individuals or species variation in life-histories or physiological parameters may simply be the by-product of contaminant exposure (Carere et al. 2010; Frederick and Jayasena 2011; Tartu et al. 2013). For example, several persistent organic pollutants (POPs) can cause reproductive failure in free-living birds through different mechanisms, such as eggshell thinning, embryo mortality, or alterations of reproductive behaviors (e.g., Burger and Gochfeld 2004; Bustnes et al. 2003, 2012). Biomagnification of the non-essential metal mercury in food webs is also a great cause of concern, because it causes detrimental effects on behavior, neurology, endocrinology, or development in humans and wildlife (Scheuhammer et al. 2007; Tan et al. 2009; Frederick 
and Jayasena 2011; Tartu et al. 2013). Moreover, it has been shown in some studies that both organic and non-organic contaminants can increase generation of oxidative damage (Metodiewa and Dunford 1990; Whysner and Wang 2001; Isaksson 2010). Therefore, contaminants and oxidative stress might interact, possibly exacerbating costs of reproduction and of other life history stages. This may be especially true for top predators (e.g., seabirds, birds of prey) in which accumulation of contaminants in the body is higher (biomagnification).

In this study, we assessed the effects of reproduction, persistent organic pollutants (organochlorine pesticides and PCBs), mercury, individual age (3-47 years), and sex on the levels of plasma oxidative damage and inflammation. To this end, we performed a crosssectional study on known-age free-living wandering albatrosses (Diomedea exulans), a large and very long-lived species ( $\approx 50$ years). We make use of an exceptional long-term dataset (Weimerskirch et al. 1997) to identify the history of each bird. The non-breeding part of the albatross population is composed of young, immature birds that have never bred before and middle-aged or old birds that have considerable breeding experience but did not breed over the course of the field study (Weimerskirch et al. 1997). Using the non breeding component of a population offered us the opportunity to have a control group for the breeding season during which we carried out the field work; this is a crucial aspect that field studies have invariably failed to include in tests of the oxidative cost of reproduction (Metcalfe and Monaghan 2013). Furthermore, wandering albatrosses bear high levels of some contaminants in their tissues (Hindell et al. 1999; Blévin et al. 2013), a feature that makes these seabirds a suitable species to investigate the effects of POPs and mercury on plasma oxidative damage and inflammation.

\section{Materials and methods}

Study area and birds

The field study was carried out on Possession Island in the southwestern Indian Ocean $\left(46.8^{\circ} \mathrm{S}, 51.8^{\circ} \mathrm{E}\right)$, where $300-400$ pairs of wandering albatrosses nest each year. Wandering albatrosses return to their breeding grounds in December and females lay a single egg in late December-early January. Both parents incubate alternatively until hatching in March. All birds had been ringed as part of a long-term mark-recapture program (Weimerskirch et al. 
1997), with nestlings being ringed since 1965. From 21 December 2007 to 4 March 2008, we captured wandering albatrosses on the breeding grounds and a sample of venous blood was taken from the tarsus within $3 \mathrm{~min}$ of capture with a 1-ml heparinized syringe and a 25-gauge needle. The volume of the blood draws never exceeded $0.05 \%$ of the bird's body mass (8-12 $\mathrm{kg}$ ). The blood was centrifuged to separate plasma (for POPs, oxidative damage, and inflammation analyses) from red blood cells (for total mercury and molecular sexing), which were then stored at $-20{ }^{\circ} \mathrm{C}$ until laboratory analyses. Sample sizes varied across analyses because we could not collect all the data from each individual: breeding males were 40-46; breeding females were 27-33; non-breeding males were 20-33; non-breeding females were 7-11 (for sample sizes, see also figure captions). Birds were sexed by molecular sexing according to Fridolfsson and Ellegren (1999). Data on oxidative damage and inflammation have been previously published by our group in an article in relation to aging of albatrosses (Lecomte et al. 2010). Here, we are revisiting this database in order to simultaneously analyze the effects of breeding activity and body contaminant levels on oxidative damage and inflammation.

Measurement of plasma oxidative damage

The Cayman's TBARS assay (Cayman Chemical, Ann Arbor, USA) was used to measure the thiobarbituric acid reactive substances in plasma. This method provides a general quantification of oxidative damage molecules that occur in the plasma, such as those generated by lipid peroxidation or carbonylation. The principle of the assay is based on the formation of an adduct between the thiobarbituric acid and the oxidative damage molecules under high temperature $\left(90-100{ }^{\circ} \mathrm{C}\right)$ and acidic conditions, which generates a color directly proportional to the concentration of oxidative damage molecules. First, $10 \mu \mathrm{l}$ of each plasma sample or standard were added to $10 \mu \mathrm{l}$ of sodium dodecyl sulfate into $500-\mu 1$ vials, and mixed. Then, $400 \mu \mathrm{l}$ of color reagent (132.5 mg of thiobarbituric acid diluted into $12.5 \mathrm{ml}$ of an acetic acid solution and $12.5 \mathrm{ml}$ of a sodium hydroxide solution) were added to each plasma solution, and capped vials were kept in boiling water for $1 \mathrm{~h}$. After $1 \mathrm{~h}$, the vials were removed from boiling water and immediately put on ice for $10 \mathrm{~min}$ in order to stop the reaction. Finally, $150 \mu \mathrm{l}$ of each solution were randomly pipetted in well plates and readings were taken at $530 \mathrm{~nm}$. Standard curves were obtained from serial dilutions of an initial 
standard of MDA (from 0 to $50 \mu \mathrm{M}$ ). The coefficient of variation of measures was $9.0 \%$.

Measurement of haptoglobin

Plasma haptoglobin (inflammation-inducible protein) was measured using a colorimetric assay (Tri-Delta Development, Ireland) based on hemoglobin-binding reaction. In plasma, haptoglobin binds free hemoglobin released from erythrocytes, so inhibiting its pro-oxidative activity. First, $7.5 \mu \mathrm{l}$ of each plasma sample or standard were randomly pipetted in well plates. To each well, $100 \mu \mathrm{l}$ of a solution of hemoglobin and $140 \mu \mathrm{l}$ of a solution of chromogen were added, respectively. Plates were then agitated and left to incubate for $5 \mathrm{~min}$ at room temperature. Then, solutions were read at $630 \mathrm{~nm}$. Standard curves were obtained from serial dilutions of an initial standard $(0-2.5 \mathrm{mg} / \mathrm{ml})$. The coefficient of variation of measures was $3.7 \%$.

\section{Measurement of mercury}

Total mercury was analyzed in red blood cells, which indicates short-term exposure (Kahle and Becker 1999; Tartu et al. 2013; Goutte et al. 2014). Total mercury (Hg) was quantified with an Altec AMA 254 spectrophotometer (aliquots mass: 5-10 mg dry weight, dw; see also Bustamante et al. 2006). All analyses were repeated 2-3 times until having a relative standard deviation $<5 \%$. Accuracy was checked using a certified reference material (CRM; Tort-2 Lobster Hepatopancreas, NRC, Canada; certified Hg concentration: $0.27 \pm 0.06 \mu \mathrm{g} / \mathrm{g} \mathrm{dw}$ ). Our measured values were $0.24 \pm 0.02 \mu \mathrm{g} / \mathrm{g} \mathrm{dw}, n=31$. Blanks were analyzed at the beginning of each set of samples and the detection limit of the method was $0.005 \mu \mathrm{g} / \mathrm{g} \mathrm{dw}$. Mean values of replicates were used in statistical analyses.

\section{Measurement of POPs}

The targeted compounds included seven indicator PCBs (CB-28, -52, -101, -118, -138, -153, and -180 ), and 10 organochlorine pesticides. The compounds chosen for further investigation were CB-99, -105, -118, -128, -138, -153, -180, -183, -187, and -194, and the $\Sigma$ pesticides ( $p, p$-DDE, HCB, cis-chlordane, trans-nonachlor). Certified solutions containing all analytes at 
$2 \mathrm{ng} / \mu \mathrm{l}$ each were obtained from LGC Standards (Molsheim, France). To each plasma sample of $100 \mu$, internal standards ( $1 \mathrm{ng}$ each) were added gravimetrically: PCBs 30, 103, 155, and 198 were used to quantify PCBs and $p, p^{\prime}$-DDT-d8 was used to quantify pesticides, respectively. All standards were provided by either Dr Ehrenstorfer or Cambridge Isotope Laboratory (via Cluzeau Info Labo, Sainte-Foy-La-Grande, France). POPs were extracted using $1 \mathrm{ml}$ of pentane:dichloromethane (90:10; v/v); after centrifugation (2,000 rpm, 2 min at $4{ }^{\circ} \mathrm{C}$ ), the organic layer was collected and the operation was repeated. Both extracts were combined and purified on an acid silica gel column (40\% sulphuric acid, $\mathrm{H}_{2} \mathrm{SO}_{4}$ ). After extract loading, analytes were eluted with $3 \times 5 \mathrm{ml}$ of pentane/dichloromethane (90/10; v/v). The extract was then concentrated using a Rapid-Vap vacuum evaporation system from Labconco (Kansas City, MO, USA) to a volume of $1 \mathrm{ml}$; it was then further concentrated under a gentle stream of nitrogen $\left(40{ }^{\circ} \mathrm{C}\right)$ after addition of $100 \mu \mathrm{l}$ of isooctane as solvent keeper. A syringe standard (octachloronaphtalene, $1 \mathrm{ng}$ ) was finally added to quantify internal standards and to assess their recovery rate for each sample (68-108\%). Final extracts were analyzed by gas chromatography coupled with electron capture detection (GC-ECD) as described elsewhere (Tapie et al. 2011). The quality control was done by means of the analysis of procedural blanks (clean and empty glass tubes treated like a sample, one run for 8 samples). Chicken plasma samples (Sigma-Aldrich, St Quentin Fallavier, France) spiked at 3 $\mathrm{ng} / \mathrm{g}$ were also analyzed; the recovery rates of PCBs and organochlorine pesticides were in the range $77-103 \%$ with coefficients of variation lower than $17 \%(n=5)$, except for CB-52 (22 $\%$ ) and mirex (29\%). POPs levels were blank corrected and the detection limit (LoD) was set at two times the mean blank value; for analytes that were not detected in blanks, LoD was determined as the concentration with a signal to noise ratio of 3. Overall, LoDs ranged from 0.09 to $0.76 \mathrm{ng} / \mathrm{g}$ wet weight. Additionally, serum total lipids were measured on an aliquot of $10 \mu \mathrm{l}$ by the sulfo-phospho-vanillin (SPV) method for colorimetric determination (e.g., Houde et al. 2006). Ecological effects of POPs will be fully discussed in a separate article.

\section{Statistical analyses}

Analyses were carried out using STATISTICA (v.10; Stat-Soft, Tulsa, OK, USA). We used generalized linear models with a backward removal (critical $P$ value at 0.05 ) to build the 
minimum model significantly explaining the observed variance. A normal distribution and identity link function was used for the plasma oxidative damage; a normal distribution and log link function was used for haptoglobin. In each model, we included the individual reproductive status at the time of bleeding (breeding vs. non-breeding) and the sex as main factors, and the individual age as a covariate. We also included the concentration of mercury or an index of organohalogenated contaminant concentration as covariate. Two-way interactions were also included. In the non-breeding cohort of our population, we included both individuals that were sexually mature or were not (i.e., $<6$ years of age; Weimerskirch et al. 1997) because they did not differ in oxidative damage nor in haptoglobin $(P \geq 0.26)$. In the breeding cohort, we had some pairs (14-17); however, we did not include it in the models because preliminary analyses showed that a pair never significantly explained variation in oxidative damage nor in haptoglobin $(P \geq 0.85)$. Importantly, breeding and non-breeding birds did not differ in age in all databases used for the statistical analyses ( $t$ test: $P \geq 0.11$; e.g., in the larger database, the mean age and standard error were $23.9 \pm 1.3$ years and $23.1 \pm 2.4$ years for breeding $(n=71)$ and non-breeding $(n=44)$ birds, respectively). In our dataset, there was no multicollinearity because the variance inflation factor was always $<2$.

As an index of organohalogenated contaminant concentration, we used the first or the second principal component that we extracted from a principal component analysis (PCA) on the correlation matrix of organohalogenated toxicants. We excluded from the statistical analyses levels of contaminants that had low loadings in a preliminary PCA or that had values below the detection limit. In the end, 13 organohalogenated chemicals met our requirements to enter in the final models. Two PCAs were run for oxidative damage and haptoglobin databases, separately. In both cases, the first two principal components explained $67 \%$ of the total variance of contaminants for the oxidative damage database $(\mathrm{PC} 1=44 \%, \mathrm{PC} 2=23 \%)$ and for the haptoglobin database $(\mathrm{PC} 1=45 \%, \mathrm{PC} 2=22 \%$; Table 1$)$, respectively. Of the 13 compounds, only $\gamma-\mathrm{HCH}$ and $\mathrm{CB}-180$ had low loadings on the two main axes of variation. We have therefore tested their effect on oxidative damage or inflammation separately. Given that their effect was not significant (data not shown), we have not discussed them. Since blood volume was not always sufficient to carry out all physiological and contaminant analyses, and since outliers were excluded from the database, sample sizes differed among statistical models (see figure captions). 


\section{Results}

Plasma oxidative damage and mercury

Breeding albatrosses had higher levels of plasma oxidative damage than non-breeding birds (Fig. 1; Table 2); older non-breeding individuals tended to have a higher oxidative damage level than younger individuals, but the relationship between age and oxidative damage did not appear in breeding birds (Fig. 2; Table 2). Differences between males and females in oxidative damage were affected by the individual load of mercury: females having high mercury concentration suffered higher oxidative damage $(r=0.34, P=0.038)$, while males showed an opposite, although non-significant pattern $(r=-0.20, P=0.078$; Fig. 3; Table 2).

Plasma oxidative damage and persistent organic pollutants

In the model where the PC1 was included as a covariate (Table 2), similar differences between breeding and non-breeding individuals emerged as for the model of mercury; moreover, birds with high levels of organohalogenated toxicants had higher levels of oxidative damage (Fig. 4). In the model with PC2 as a covariate (Table 2), a difference again emerged between breeding and non-breeding birds in oxidative damage level.

Haptoglobin and mercury

Mercury did not affect the concentration of haptoglobin. The final minimum model showed only a significant interaction between reproductive status and sex (Table 2): while haptoglobin concentration in non-breeding individuals was similar between males and females, haptoglobin was higher in breeding females than in breeding males (Fig. 5).

Haptoglobin and persistent organic pollutants

PC1 and PC2 did not significantly influence the concentration of haptoglobin. As for the model with mercury, only the interaction between reproductive status and sex was significant (Table 2). 


\section{Discussion}

The results of our study show for the first time in a free-living vertebrate that breeding individuals may have higher plasma oxidative damage than non-breeding individuals. Levels of the inflammatory protein haptoglobin were similar between breeding and non-breeding birds, with the exception of breeding males which had the lowest levels of haptoglobin. Our data also show an effect of age and contaminants on the plasma oxidative damage level, but not on plasma haptoglobin. The cost of reproduction is a central paradigm of life-history theory (Stearns 1992). We currently know very little about the currency of costs of reproduction. It has been suggested that oxidative stress may be one key cellular mechanism underlying the costs of reproduction (Costantini 2008; Metcalfe and Alonso-Alvarez 2010). However, there is not a general consensus (Metcalfe and Monaghan 2013). The few studies in which reproductive effort was manipulated, for example, found that enzymatic and nonenzymatic antioxidant defences may be altered, possibly sacrificed in favor of investment in reproduction (Alonso-Alvarez et al. 2004; Wiersma et al. 2004; Losdat et al. 2011) or upregulated in response to an increase in free radical production (Garratt et al. 2013). Moreover, while the increase in egg production effort may induce an increase in plasma oxidative damage (Travers et al. 2010), experimental increases of offspring rearing effort did not result in an increase in oxidative damage (Garratt et al. 2013). Metabolic costs of reproduction may also be induced by increases in sexual hormones that accompany the transition from a nonreproducing to a reproducing state (Alonso-Alvarez et al. 2007; Casagrande et al. 2012). Our data were collected in a way that does not allow us to disentangle the relative contributions of changes in hormonal status and effort in egg production or chick rearing. Regardless of mechanisms, our findings provide evidence, at least in this particular species, that reproductively active individuals may have higher plasma oxidative damage than individuals of comparable age that are not breeding. In contrast to oxidative damage, results on haptoglobin apparently provided a different picture. While reproducing and non-reproducing females did not differ, reproducing males had lower levels of plasma haptoglobin than nonreproducing males and all females. Haptoglobin is a well-known acute phase protein that indicates an ongoing inflammatory response, and is found in a wide range of taxa, including birds. Haptoglobin normally circulates at low levels, but concentrations increase during inflammatory responses. It exerts an antioxidant activity because it binds free hemoglobin 
released from erythrocytes, so inhibiting its pro-oxidative activity mediated by iron (Jelena et al. 2013). Studies on various bird species have found that haptoglobin concentration is a distinctive trait of an individual and has the capacity to predict endotoxin-induced changes in concentration of this acute phase protein (Matson et al. 2012). A decrease in circulating haptoglobin is often reported as an index of a status of haemolytic anaemia (Körmöczi et al. 2006). We do not know why haptoglobin in breeding males was lower than other birds. It might suggest that breeding males were in better health status (e.g., in cases in which the parasite load was low) than other birds. In particular, the high levels of haptoglobin in nonbreeding birds might indicate that they skipped reproduction because of a poor health status. However, the previously described association between low haptoglobin concentration and hemolytic anemia (Körmöczi et al. 2006) requires caution in interpretation. Further studies will, therefore, be needed to ascertain the role of haptoglobin as a parameter of health status in albatrosses.

Our data also show that older individuals had a higher plasma oxidative damage level than younger individuals. However, the increase in plasma oxidative damage with individual chronological age only emerged in non-breeding birds. Previous work on the same population of breeding wandering albatrosses showed that individual age strongly affected foraging behavior and reproductive performance, but was unrelated to physiological measures like immune markers or hormones (Lecomte et al. 2010). Another study on a different population of wandering albatrosses revealed that declines in performance with age are followed by a striking increase in breeding success and a key parental investment trait at the final breeding attempt (Froy et al. 2013). Physiological changes typical of reproduction might therefore have hidden the relationship between age and accumulation/overproduction of oxidative damage. Breeding albatrosses tended to have higher levels of plasma oxidative damage than nonbreeding birds regardless of individual age. When birds are around 40 years old, however, the differentiation in oxidative damage between breeding and non-breeding birds became less evident, probably because of a terminal increase in damage in non-breeding birds. From our dataset, it is unclear whether the increase in oxidative damage reflects senescence and why such an increase in older individuals was not observed in breeding birds. Individual age was strongly correlated with the number of lifetime individual breeding events $(r=0.83, P<$ 0.001). Hence, the increase in damage with age might also reflect reproduction-induced accumulation of damage. Our data are cross-sectional, which makes it impossible to separate 
within-individual ageing patterns from between individual heterogeneity and any effects of differential survival among phenotypes. Our results suggest that a careful selection of relevant markers of physiological oxidative status is needed to test whether or not the observed terminal increases in reproductive investment in wandering albatrosses or other species are independent of individual state.

Individual contaminant load significantly contributed to explain variation in oxidative damage but not in inflammation. Albatrosses carrying higher levels of POPs had higher oxidative damage. Our data are in line with a recent meta-analysis showing a significant impact of pollution on various classes of antioxidants and oxidative damage in wild animals (Isaksson 2010). Although our analysis was restricted to a single biomarker of oxidative damage in plasma, Isaksson (2010) showed that thiobarbituric acid reactive substances in blood are a sensitive biomarker to contaminant exposure. POPs may cause oxidative stress through various routes, like increases in superoxide anion production (Metodiewa and Dunford 1990) or free iron release from metalloproteins (Whysner and Wang 2001). POPs might also cause oxidative stress through increases in corticosterone secretion (Costantini et al. 2011). This is relevant because studies on kittiwakes (Rissa tridactyla) and glaucous gulls (Larus hyperboreus) found that baseline corticosterone concentration was higher in those birds with higher POPs burden (Verboven et al. 2010; Nordstad et al. 2012). Preliminary data also show that corticosterone increases with POP levels in wandering albatrosses (Alizée Meillere and Sabrina Tartu, unpublished data). Previous studies on seabirds have also shown that exposure to POPs may cause changes in the oxidative balance (Hegseth et al. 2011; Bourgeon et al. 2012) and reduce survival (Erikstad et al. 2013). Overall, these findings suggest that oxidative stress might be a plausible mechanism involved in the reduction of longevity in individuals highly contaminated with POPs.

As regards mercury, females having high mercury concentration in red blood cells (Carravieri et al., unpublished data) suffered high plasma oxidative damage. In contrast, males showed an opposite but non-significant pattern. This difference between sexes in the relationship between mercury and oxidative damage is possibly explained by females (mean level of 10.3 $\mu \mathrm{g} / \mathrm{g}$ dry weight) carrying higher levels of mercury than males (mean level of $6.3 \mu \mathrm{g} / \mathrm{g}$ dry weight). Similarly, Tavares et al. (2013) found that females had significantly higher levels of mercury in red blood cells than males in wandering albatrosses from South Georgia. Results on wandering albatrosses differ from those of previous studies on various fish-eating bird 
species, which found that mercury concentrations in males are in most cases higher than females (Monteiro and Furness 1995; Robinson et al. 2012). Such difference in albatrosses might be driven by males and females foraging on different prey or different environments (Weimerskirch et al. 1993) that expose them to differing mercury threats. If foraging strategies differ between males and females, this may also contribute to explain the higher plasma oxidative damage of females if, for example, their diet is richer in unsaturated fatty acids or if the foraging cost for females is higher.

Mercury is a highly toxic non-essential metal that negatively influences humans and wildlife (Tan et al. 2009). Our data suggest that mercury might also negatively impact on females through an increase in oxidative stress. The increase in damage with mercury level was, however, similar between reproducing and non-reproducing birds.

In birds, mercury is excreted through its deposition in the feathers during the molt (Monteiro and Furness 1995). In this pathway, mercury binds to keratin sulfhydryl groups during synthesis of feathers. Seabirds with slow molt cycles, such as albatrosses, may, however, have a limited capacity for mercury elimination through feathers (Thompson and Furness 1989). Mercury may also be excreted from the body through the glutathione pathway. Mercury binds to the sulfhydryl groups on glutathione or on other thiols and forms a complex that is finally excreted in the feces (Ballatori and Clarkson 1985). Sulfhydryl groups like thiols are important molecules that regulate the oxidative balance and any depletion leads to disruption of redox signaling and control and an increase in oxidative stress (Jones 2006). High contamination with mercury might lead to a high depletion of thiols regardless of the pathway of excretion, which may compromise defenses against oxidation. Consequent depletion of glutathione to mercury contamination may, for example, compromise the activity of the enzyme glutathione peroxidase (Hoffman and Heinz 1998), which uses glutathione as a cofactor to detoxify the organism from peroxides and hydroperoxides. Importantly, the activity of selenium dependent glutathione peroxidase may be further compromised by depletion of selenium that is being used to biosynthesize mineral granules containing mercury and selenium in the liver (Nigro and Leonzio 1996). Our results raise the need of further studies to elucidate the consequences of oxidative stress induced by mercury in this threatened seabird species. In particular, further studies are needed to assess whether oxidative stress induced by mercury impinges on reproductive fitness or on other fitness-related traits.

In conclusion, results of our study support the hypothesis that oxidative stress may be higher 
in reproducing individuals, possibly reflecting a transient increase in damage over the breeding phase. Our results also suggest that the individual oxidative stress level may be shaped by the interaction between exposure to contaminants and other factors, such as sex. Finally, our data provide evidence that plasma oxidative damage is higher in non-breeding older individuals. We highlight the need of future studies in order to tease apart the mechanisms (e.g., hormones, parental effort) that contribute to increase the oxidative damage level in breeding individuals. We also highlight the need of using additional biomarkers of oxidative damage in order to assess whether the effects of reproduction and contaminants on oxidative balance are systemic or are limited to particular molecular classes or body tissues.

Acknowledgments: We thank the editor and two anonymous reviewers for providing valuable comments that helped us to improve presentation and interpretation of results. This project was supported by Agence Nationale de la Recherche (ANR PolarTop, O. Chastel) and the French Polar Institute (IPEV, program 109, H. Weimerskirch), Terres Australes et Antarctiques Françaises, Zone Atelier de Recherches sur l'Environnement Antarctique et Subantarctique (CNRS-INEE). B. Faivre and G. Sorci received financial support from the Agence Nationale de la Recherche (ANR STRESS OX and AGE). Field procedures and blood sampling were authorized by the Ethics Committee of IPEV and by the Comite de l'Environnement Polaire. A. Carravieri was supported by a $\mathrm{PhD}$ grant from the PoitouCharentes Region. The authors thank A. Jaeger, H. Maheo, and M. Berlincourt for their assistance in the field; A. Goutte for providing valuable comments on an earlier draft; all the wintering fieldworkers involved in the long-term monitoring programs for their help on the field; and D. Besson, K. Delord and S. Tartu for great help in the POP analysis and for managing the long-term database. This study has been carried out in the framework of the Cluster of Excellence COTE (ANR-10-LABX-45). The Aquitaine Region and the European Union (CPER A2E project) are acknowledged for their financial support. Europe is moving in Aquitaine with the European Regional Development Fund (FEDER).

\section{References}

Alonso-Alvarez C, Bertrand S, Devevey G, Prost J, Faivre B, Sorci G (2004) Increased susceptibility to oxidative stress as a proximate cost of reproduction. Ecol Lett 7:363-368

Alonso-Alvarez C, Bertrand S, Faivre B, Chastel O, Sorci G (2007) Testosterone and oxidative stress: the oxidation handicap hypothesis. Proc R Soc Lond B 274:819-825

Ballatori N, Clarkson TW (1985) Biliary secretion of glutathione and glutathione-metal complexes. Fundam Appl Toxicol 5:816-831

Blévin P, Carravieri A, Jaeger A, Chastel O, Bustamante P, Cherel Y (2013) Wide range of mercury contamination in chicks of southern ocean seabirds. PLoS ONE 8:e54508

Bourgeon S, Leat EH, Magnusdóttir E, Fisk AT, Furness RW, Strøm H, Hanssen SA, Petersen A, Olafsdóttir K, Borgå K, Gabrielsen GW, Bustnes JO (2012) Individual variation in biomarkers of health: influence of persistent organic pollutants in Great skuas Stercorarius skua breeding at different geographical locations. Environ Res 118:31-39

Burger J, Gochfeld M (2004) Marine birds as sentinels of environmental pollution. EcoHealth 
$1: 263-274$

Bustamante P, Lahaye V, Durnez C, Churlaud C, Caurant F (2006) Total and organic Hg concentrations in cephalopods from the North East Atlantic waters: influence of geographical origin and feeding ecology. Sci Tot Environ 368:585-596

Bustnes JO, Erikstad KE, Skaare JU, Bakken V, Mehlum F (2003) Ecological effects of organochlorine pollutants in the Arctic: a study of the glaucous gull. Ecol Applic 13:504515

Bustnes JO, Moe B, Hanssen SA, Herzke D, Fenstad AF, Nordstad T, Borgå K, Gabrielsen GW (2012) Temporal dynamics of circulating persistent organic pollutants in a fasting seabird under different environmental conditions. Environm Sci Technol 46:10287-10294

Carere C, Costantini D, Sorace A, Santucci D, Alleva E (2010) Bird populations as sentinels of endocrine disrupting chemicals. Ann Ist Super Sanità 46:81-88

Casagrande S, Costantini D, Dell'Omo G, Tagliavini J, Groothuis TGG (2012) Differential effects of testosterone metabolites oestradiol and dihydrotestosterone on oxidative stress and carotenoid-dependent colour expression in a bird. Behav Ecol Sociobiol 66:1319-1331

Costantini D (2008) Oxidative stress in ecology and evolution: lessons from avian studies. Ecol Lett 11:1238-1251

Costantini D, Marasco V, Møller AP (2011) A meta-analysis of glucocorticoids as modulators of oxidative stress in vertebrates. J Comp Physiol B 181:447-456

Dell'Omo G ( 2002) Behavioural Ecotoxicology Wiley and Sons, New York

Erikstad KE, Sandvik H, Reiertsen TK, Bustnes JO, Strøm H (2013) Persistent organic pollution in a high-Arctic top predator: sex-dependent thresholds in adult survival. Proc $\mathrm{R}$ Soc Lond B 280:20131483

Frederick P, Jayasena N (2011) Altered pairing behaviour and reproductive success in white ibises exposed to environmentally relevant concentrations of methylmercury. Proc R Soc Lond B 278:1851-1857

Fridolfsson AK, Ellegren H (1999) A simple and universal method for molecular sexing of non-ratite birds. J Avian Biol 30:116-121

Froy H, Phillips RA, Wood AG, Nussey DH, Lewis S (2013) Age-related variation in reproductive traits in the wandering albatross: evidence for terminal improvement following senescence. Ecol Lett 16:642-649

Garratt M, Pichaud N, King EDA, Brooks RC (2013) Physiological adaptations to reproduction I Experimentally increasing litter size enhances aspects of antioxidant defence but does not cause oxidative damage in mice. J Exp Biol 216:2879-2888

Goutte A, Bustamante P, Barbraud C, Delord K, Weimerskirch H, Chastel O (2014) Demographic responses to mercury exposure in two closely-related Antarctic top predators. Ecology, in press

Halliwell BH, Gutteridge JMC (2007) Free radicals in biology and medicine 4th edn. Oxford University Press, Oxford

Hegseth MN, Camus L, Gorbi S, Regoli F, Gabrielsen GW (2011) Effects of exposure to halogenated organic compounds combined with dietary restrictions on the antioxidant defense system in herring gull chicks. Sci Tot Environ 409:2717-2724

Hindell MA, Brothers N, Gales R (1999) Mercury and cadmium concentrations in the tissues of three species of southern albatrosses. Polar Biol 22:102-108

Hoffman DJ, Heinz GH (1998) Effects of mercury and selenium on glutathione metabolism and oxidative stress in mallard ducks. Environ Toxicol Chem 17:161-166

Houde M, Pacepavicius G, Wells RS, Fair PA, Letcher RJ, Alaee M, Bossart GD, Hohn AA, Sweeney J, Solomon KR, Muir DC (2006) Polychlorinated biphenyls and hydroxylated 
polychlorinated biphenyls in plasma of bottlenose dolphins Tursiops truncatus from the Western Atlantic and the Gulf of Mexico. Environ Sci Technol 40:5860-5866

Isaksson C (2010) Pollution and its impact on wild animals: a meta-analysis on oxidative stress EcoHealth 7:342-350

Jelena A, Mirjana M, Desanka B, Svetlana IM, Aleksandra U, Goran P, Ilijana G (2013) Haptoglobin and the inflammatory and oxidative status in experimental diabetic rats: antioxidant role of haptoglobin. J Physiol Biochem 69:45-58

Jones DP (2006) Redefining oxidative stress. Antioxid Redox Signal 8:1865-1879

Kahle S, Becker PH (1999) Bird blood as bioindicator for mercury in the environment. Chemosphere 39:2451-2457

Ketterson ED, Nolan VJ (1992) Hormones and life histories: an integrative approach. Am Nat 140:S33-S62

Koivula MJ, Eeva T (2010) Metal-related oxidative stress in birds. Environ Poll 158:23592370

Körmöczi GF, Säemann MD, Buchta C, Peck-Radosavljevic M, Mayr WR, Schwartz DW, Dunkler D, Spitzauer S, Panzer S (2006) Influence of clinical factors on the haemolysis marker haptoglobin. Eur J Clin Invest 36:202-209

Lecomte VJ, Sorci G, Cornet S, Jaeger A, Faivre B, Arnoux E, Gaillard M, Trouvé C, Besson D, Chastel O, Weimerskirch H (2010) Patterns of aging in the long-lived wandering albatross. Proc Natl Acad Sci USA 107:6370-6375

Losdat S, Helfenstein F, Gaude B, Richner H (2011) Reproductive effort transiently reduces antioxidant capacity in a wild bird. Behav Ecol 22:1218-1226

Matson KD, Horrocks NP, Versteegh MA, Tieleman BI (2012) Baseline haptoglobin concentrations are repeatable and predictive of certain aspects of a subsequent experimentally-induced inflammatory response. Comp Biochem Physiol Part A 162:7-15

Metcalfe NB, Alonso-Alvarez C (2010) Oxidative stress as a life-history constraint: the role of reactive oxygen species in shaping phenotypes from conception to death. Funct Ecol 24:984-996

Metcalfe NB, Monaghan P (2013) Does reproduction cause oxidative stress? An open question. Trend Ecol Evol 28:347-350

Metodiewa D, Dunford HB (1990) The role of myeloperoxidase in the oxidation of biologically active polyhydroxyphenols substituted catechols. Eur J Biochem 193:445-448

Monteiro LR, Furness RW (1995) Seabirds as monitors of mercury in the marine environment. Water Air Soil Pollut 80:851-870

Nigro M, Leonzio C (1996) Intracellular storage of mercury and selenium in different marine vertebrates. Mar Ecol Progr Ser 135:137-143

Nordstad T, Moe B, Bustnes JO, Bech C, Chastel O, Goutte A, Sagerup K, Trouvé C, Herzke D, Gabrielsen GW (2012) Relationships between POPs and baseline corticosterone levels in black-legged kittiwakes (Rissa tridactyla) across their breeding cycle. Environ Pollut 164:219-226

Robinson SA, Lajeunesse MJ, Forbes MR (2012) Sex differences in mercury contamination of birds: testing multiple hypotheses with meta-analysis. Environ Sci Technol 46:70947101

Scheuhammer AM, Meyer MW, Sandheinrich MB, Murray MW (2007) Effects of environmental methylmercury on the health of wild birds mammals and fish. AMBIO 36:12-19

Sorci G, Faivre B (2009) Inflammation and oxidative stress in vertebrate host-parasite systems. Philos Trans Roy Soc 364:71-83 
Stearns SC (1992) The evolution of life histories. Oxford University Press, Oxford

Tan SW, Meiller JC, Mahaffey KR (2009) The endocrine effects of mercury in humans and wildlife. Crit Rev Toxicol 39:228-269

Tapie N, Le Menach K, Pasquaud S, Elie P, Devier MH, Budzinski H (2011) PBDE and PCB contamination of eels from the Gironde estuary: from glass eels to silver eels. Chemosphere 83:175-185

Tartu S, Goutte A, Bustamante P, Angelier F, Moe B, Clément-Chastel C, Bech C, Gabrielsen GW, Bustnes JO, Chastel O (2013) To breed or not to breed: endocrine response to mercury contamination by an Arctic seabird. Biol Lett 9:20130317

Tavares S, Xavier JC, Phillips RA, Pereira ME, Pardal MA (2013) Influence of age sex and breeding status on mercury accumulation patterns in the wandering albatross Diomedea exulans. Environ Pollut 181:315-320

Thomson DR, Furness RW (1989) The chemical form of mercury stored in south Atlantic seabirds. Environ Pollut 60:305-317

Travers M, Clinchy M, Zanette L, Boonstra R, Williams TD (2010) Indirect predator effects on clutch size and the cost of egg production. Ecol Lett 13:980-988

Verboven N, Verreault J, Letcher RJ, Gabrielsen GW, Evans NP (2010) Adrenocortical function of Arctic-breeding glaucous gulls in relation to persistent organic pollutants. Gen Comp Endocrinol 166:25-32

Weimerskirch H, Salamolard M, Sarrazin F, Jouventin P (1993) Foraging strategy of wandering albatrosses through the breeding season: a study using satellite telemetry. The Auk 110:325-342

Weimerskirch H, Brothers N, Jouventin P (1997) Population dynamics of wandering albatross Diomedea exulans and Amsterdam albatross D. amsterdamensis in the Indian Ocean and their relationships with long-line fisheries: conservation implications. Biol Cons 79:257270

Whysner J, Wang CX (2001) Hepatocellular iron accumulation and increased cell proliferation in polychlorinated biphenyl-exposed Sprague-Dawley rats and the development of hepatocarcinogenesis. Toxicol Sci 62:36-45

Wiersma P, Selman C, Speakman JR, Verhulst S (2004) Birds sacrifice oxidative protection for reproduction. Biol Lett 271:360-363 
Table 1. Loadings (expressed as correlation coefficient of each single contaminant with PC1 or PC2) of variables onto the first two principal components.

\begin{tabular}{lcccc}
\hline & \multicolumn{2}{c}{ Oxidative damage } & \multicolumn{2}{c}{ Haptoglobin } \\
& PC1 & PC2 & PC1 & PC2 \\
\hline HCB & 0.509 & $\mathbf{0 . 6 5 8}$ & 0.480 & $\mathbf{0 . 6 8 5}$ \\
$\gamma$-HCH & 0.308 & 0.485 & 0.274 & 0.476 \\
PCB-52 & $\mathbf{0 . 7 0 4}$ & -0.474 & $\mathbf{0 . 7 1 9}$ & -0.458 \\
2,4-DDE & $\mathbf{0 . 7 6 1}$ & -0.066 & $\mathbf{0 . 7 6 5}$ & -0.093 \\
PCB-101 & $\mathbf{0 . 7 1 5}$ & -0.610 & $\mathbf{0 . 7 2 4}$ & -0.602 \\
Cis-chlordane & $\mathbf{0 . 7 8 8}$ & 0.314 & $\mathbf{0 . 7 9 8}$ & 0.317 \\
Trans-nonachlor & $\mathbf{0 . 6 5 3}$ & 0.518 & $\mathbf{0 . 6 5 6}$ & 0.502 \\
PCB-118 & $\mathbf{0 . 7 1 0}$ & -0.640 & $\mathbf{0 . 7 2 4}$ & -0.618 \\
4,4-DDD & $\mathbf{0 . 6 2 2}$ & 0.524 & $\mathbf{0 . 6 3 4}$ & 0.502 \\
PCB-153 & $\mathbf{0 . 8 0 0}$ & -0.210 & $\mathbf{0 . 7 9 5}$ & -0.195 \\
PCB-138 & $\mathbf{0 . 7 9 8}$ & -0.411 & $\mathbf{0 . 8 0 2}$ & -0.382 \\
PCB-180 & 0.576 & 0.040 & 0.562 & 0.067 \\
Mirex & 0.541 & $\mathbf{0 . 6 4 7}$ & 0.528 & $\mathbf{0 . 6 5 7}$ \\
\hline
\end{tabular}

The first two principal components explained $67 \%$ of the total variance of contaminants for the oxidative damage database ( $\mathrm{PC} 1=44 \%, \mathrm{PC} 2=23 \%$ ) and for the haptoglobin database $(\mathrm{PC} 1=45 \%, \mathrm{PC} 2=22 \%)$. Positive and negative loadings indicate a positive or a negative correlation between the contaminant and the PC1 or the PC2; contaminants with the same loading sign, therefore, go in the same direction. DDD = dichlorodiphenyldichloroethane, $\mathrm{DDE}=$ dichlorodiphenyldichloroethylene, $\mathrm{HCB}=$ hexachlorobenzene, $\gamma-\mathrm{HCH}=$ lindane, $\mathrm{PCB}=$ polychlorinated biphenyl. 
Table 2. Generalized linear models explaining the factors that influenced the plasma oxidative damage and plasma haptoglobin variation in wandering albatrosses.

\begin{tabular}{|c|c|c|c|c|c|c|c|c|c|c|c|c|c|}
\hline & \multicolumn{3}{|c|}{ Inital Model } & \multicolumn{3}{|l|}{ Final Model } & & \multicolumn{3}{|l|}{ Inital Model } & \multicolumn{3}{|l|}{ Final Model } \\
\hline & Oxidative damage df & Wald & $\mathrm{p}$-value & $\mathrm{df}$ & Wald & p-value & Haptoglobin & $\mathrm{df}$ & Wald & p-value & & Wald & p-value \\
\hline reprod status & 1 & 6.01 & 0.014 & 1 & 11.43 & 0.001 & & 1 & 1.94 & 0.164 & & & \\
\hline $\operatorname{sex}$ & 1 & 1.79 & 0.180 & 1 & 4.62 & 0.032 & & 1 & 1.09 & 0.296 & & & \\
\hline age & 1 & 1.88 & 0.170 & & & & & 1 & 0.04 & 0.844 & & & \\
\hline mercury & 1 & 0.15 & 0.702 & & & & & 1 & 2.51 & 0.113 & & & \\
\hline reprod status $\times$ age & 1 & 5.39 & 0.020 & 1 & 4.19 & 0.041 & & 1 & 0.07 & 0.794 & & & \\
\hline reprod status $\times$ mercury & 1 & 0.67 & 0.415 & & & & & 1 & 3.63 & 0.057 & & & \\
\hline reprod status $\times$ sex & 1 & 1.29 & 0.257 & & & & & 1 & 5.31 & 0.021 & 1 & 6.95 & 0.008 \\
\hline $\operatorname{sex} \times$ age & 1 & 0.03 & 0.859 & & & & & 1 & 2.65 & 0.103 & & & \\
\hline sex $\times$ mercury & 1 & 5.24 & 0.022 & 1 & 5.68 & 0.017 & & 1 & 0.02 & 0.896 & & & \\
\hline reprod status & 1 & 7.585 & 0.006 & 1 & 6.63 & 0.010 & & 1 & 0.206 & 0.650 & & & \\
\hline $\operatorname{sex}$ & 1 & 0.519 & 0.471 & & & & & 1 & 2.186 & 0.139 & & & \\
\hline age & 1 & 1.250 & 0.264 & & & & & 1 & 0.129 & 0.719 & & & \\
\hline PC1 & 1 & 0.869 & 0.351 & 1 & 4.27 & 0.039 & & 1 & 0.233 & 0.629 & & & \\
\hline reprod status $\times$ age & 1 & 2.891 & 0.089 & & & & & 1 & 0.053 & 0.818 & & & \\
\hline reprod status $\times \mathrm{PC} 1$ & 1 & 0.018 & 0.894 & & & & & 1 & 0.096 & 0.756 & & & \\
\hline reprod status $\times$ sex & 1 & 0.085 & 0.771 & & & & & 1 & 4.299 & 0.038 & 1 & 7.90 & 0.005 \\
\hline $\operatorname{sex} \times$ age & 1 & 0.472 & 0.492 & & & & & 1 & 2.622 & 0.105 & & & \\
\hline $\operatorname{sex} \times \mathrm{PC} 1$ & 1 & 0.798 & 0.372 & & & & & 1 & 0.778 & 0.378 & & & \\
\hline reprod status & 1 & 10.98 & 0.001 & 1 & 11.67 & 0.001 & & 1 & 0.56 & 0.456 & & & \\
\hline $\operatorname{sex}$ & 1 & 0.44 & 0.507 & & & & & 1 & 2.67 & 0.103 & & & \\
\hline age & 1 & 1.15 & 0.283 & & & & & 1 & 0.39 & 0.531 & & & \\
\hline $\mathrm{PC} 2$ & 1 & 0.02 & 0.902 & & & & & 1 & 0.13 & 0.718 & & & \\
\hline reprod status $\times$ age & 1 & 2.63 & 0.105 & & & & & 1 & 0.01 & 0.925 & & & \\
\hline reprod status $\times \mathrm{PC} 2$ & 1 & 0.00 & 0.975 & & & & & 1 & 0.39 & 0.532 & & & \\
\hline reprod status $\times$ sex & 1 & 0.00 & 0.950 & & & & & 1 & 2.04 & 0.153 & 1 & 7.90 & 0.005 \\
\hline sex $\times$ age & 1 & 0.44 & 0.509 & & & & & 1 & 2.23 & 0.136 & & & \\
\hline $\operatorname{sex} \times \mathrm{PC} 2$ & 1 & 0.21 & 0.648 & & & & & 1 & 0.01 & 0.923 & & & \\
\hline
\end{tabular}




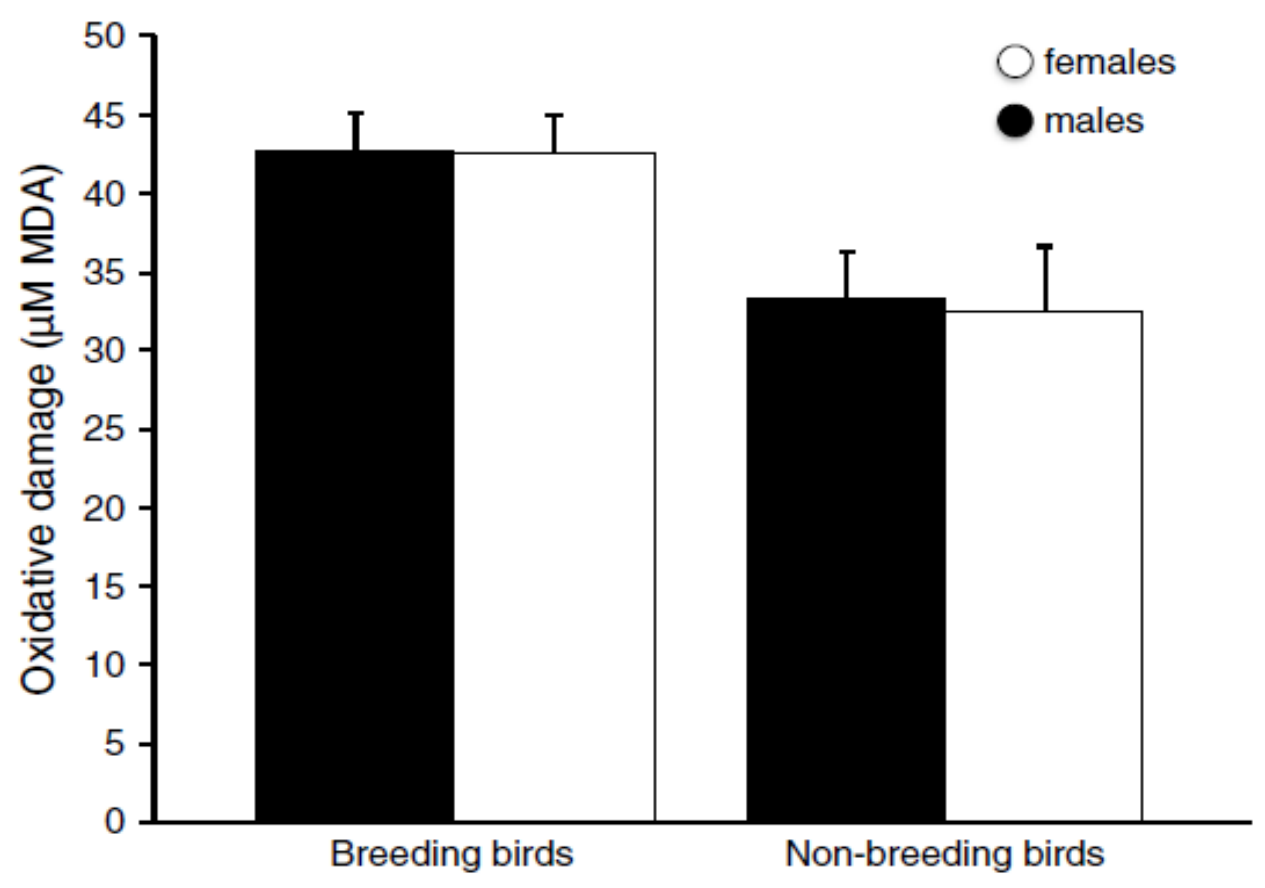

Figure 1. Breeding albatrosses (males, $n=40$; females, $n=31$ ) had higher plasma oxidative damage than non-breeding birds (males, $n=33$; females, $n=11$ ) irrespective of sex. Data are shown as mean plus standard error. 


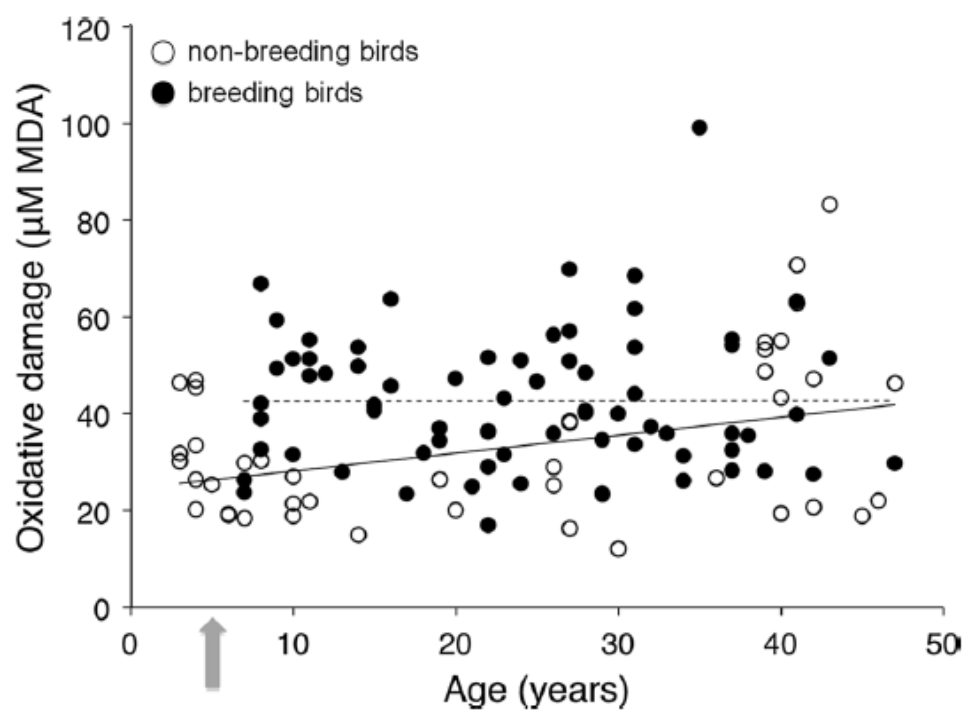

Figure 2. Plasma oxidative damage increased with individual chronological age in nonbreeding $(n=44)$ but not in breeding $(n=71)$ albatrosses. Dashed line = breeding birds; solid line $=$ non-breeding birds. The arrow indicates the age of first reproduction (6 years; Weimerskirch et al. 1997). 


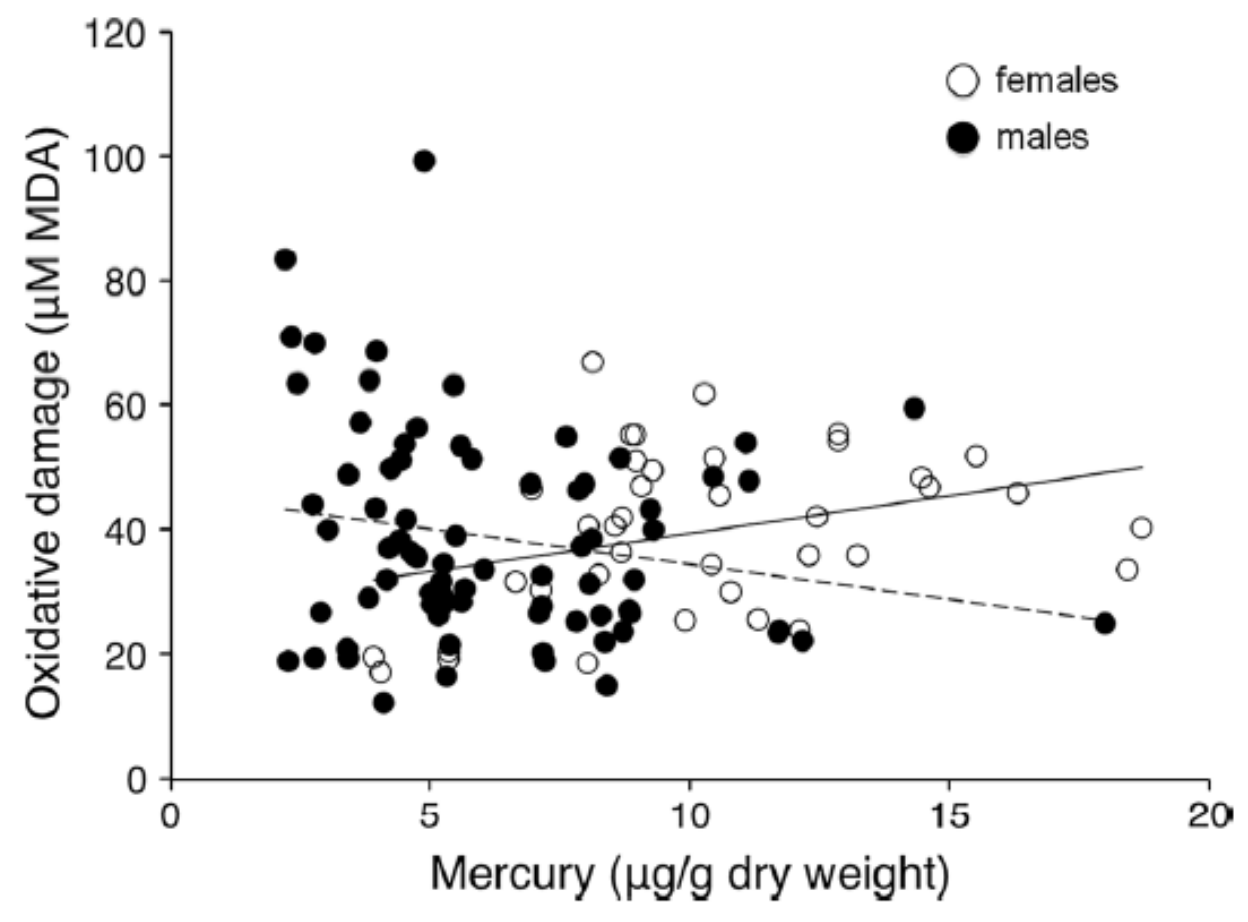

Figure 3. Plasma oxidative damage level increased with red blood cell mercury concentration in females $(n=38)$ but not in males $(n=77)$, irrespective of reproductive state. Dashed line $=$ males; solid line $=$ females. 


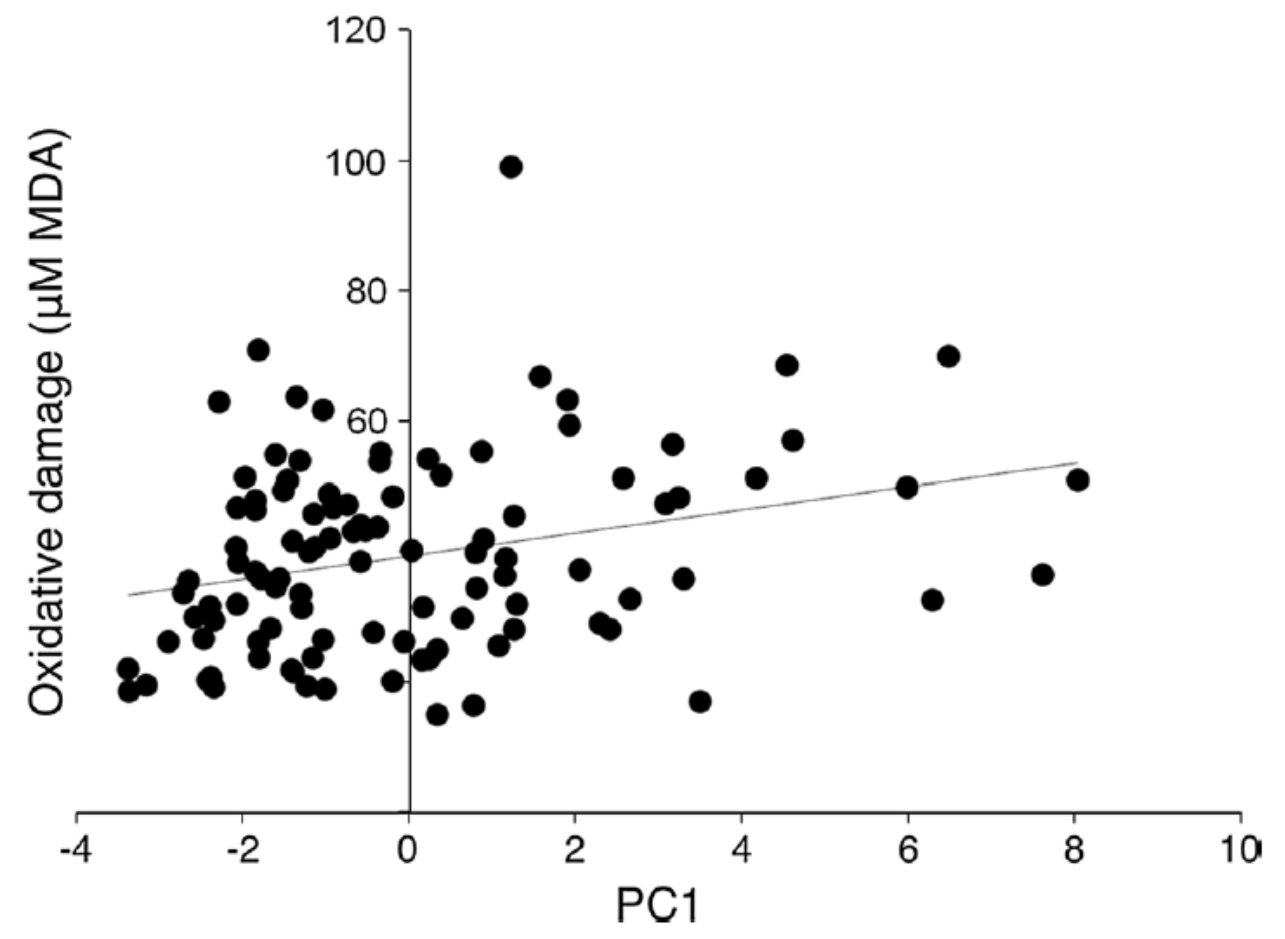

Figure 4. Plasma oxidative damage level was higher in those individuals having higher plasma levels of persistent organic pollutants $(r=0.29, n=104)$. 


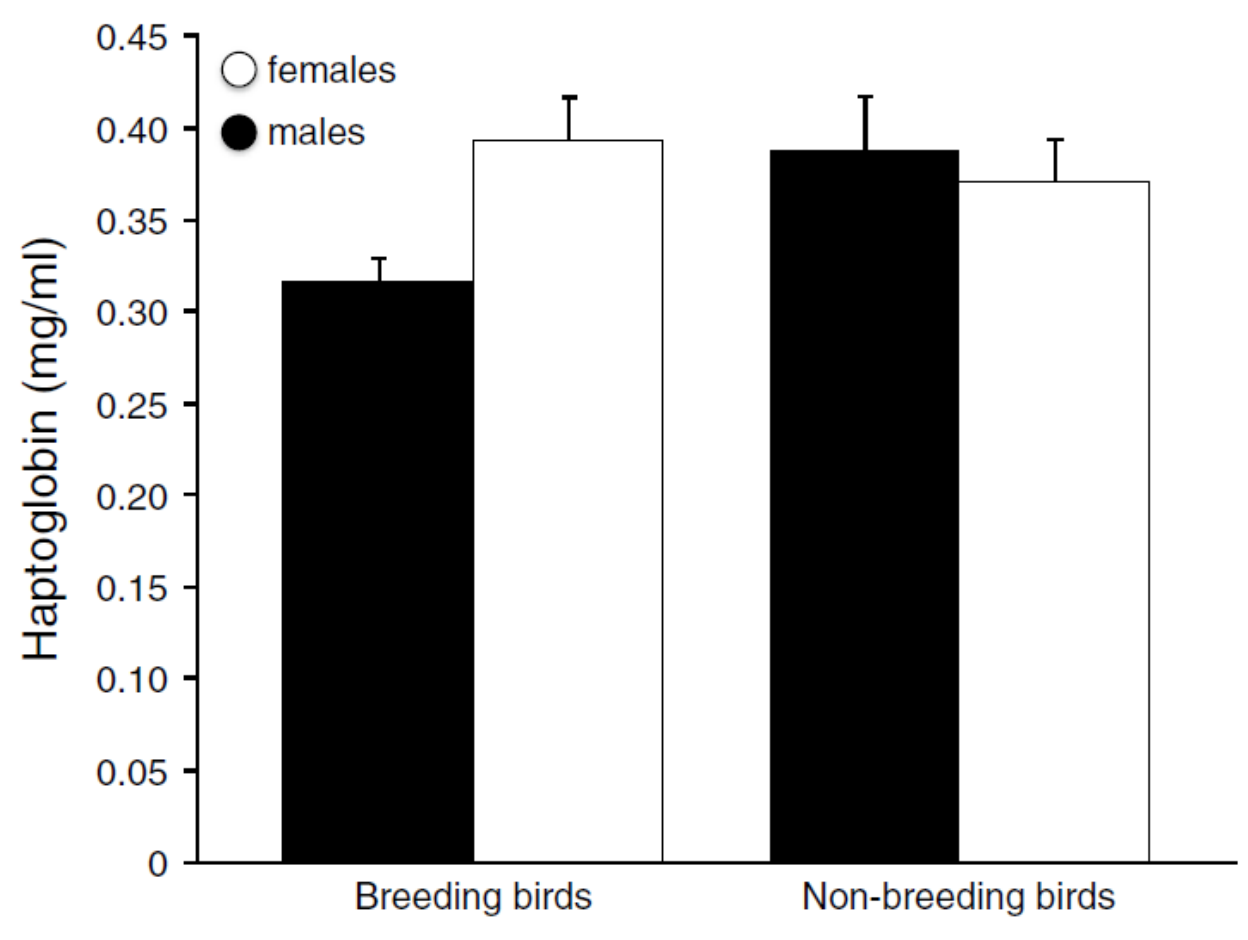

Figure 5. Breeding males $(n=40)$ had lower plasma concentrations of haptoglobin than breeding females $(n=31$; Fisher test $P=0.011)$ and non-breeding males $(n=32$; Fisher test $P$ $=0.017)$, but not of non-breeding females $(n=11$; Fisher test $P=0.197)$. Data are shown as mean plus standard error. 